Cahiers $d u$ MONDE RUSSE

\section{Cahiers du monde russe}

Russie - Empire russe - Union soviétique et États indépendants

$55 / 3-4 \mid 2014$

Varia

\title{
Anna Colin Lebedev, Le cœur politique des mères, Analyse du mouvement des mères de soldats en Russie
}

\section{Vicky Davis}

\section{(2) OpenEdition}

1 Journals

\section{Édition électronique}

URL : http://journals.openedition.org/monderusse/8105

DOI : 10.4000/monderusse. 8105

ISSN : $1777-5388$

Éditeur

Éditions de l'EHESS

\section{Édition imprimée}

Date de publication : 1 juillet 2014

Pagination : 473-475

ISBN : 978-2-7132-2441-6

ISSN : $1252-6576$

\section{Référence électronique}

Vicky Davis, «Anna Colin Lebedev, Le cœur politique des mères, Analyse du mouvement des mères de soldats en Russie », Cahiers du monde russe [En ligne], 55/3-4 | 2014, mis en ligne le 14 avril 2015,

Consulté le 22 septembre 2020. URL : http://journals.openedition.org/monderusse/8105; DOI :

https://doi.org/10.4000/monderusse.8105

Ce document a été généré automatiquement le 22 septembre 2020.

() École des hautes études en sciences sociales 


\title{
Anna Colin Lebedev, Le cœur politique des mères, Analyse du mouvement des mères de soldats en Russie
}

\author{
Vicky Davis
}

\section{RÉFÉRENCE}

Anna COLIN LEBEDEV, Le cœur politique des mères, Analyse du mouvement des mères de soldats en Russie, Paris : Éditions de l'École des hautes études en sciences sociales, 2013, 246 p.

1 In this valuable piece of sociological research Anna Colin Lebedev scrutinizes the modus operandi of a non-governmental organisation of women activists taking on the essentially male domain of the military authorities in post-Soviet Russia. With no dearth of academic studies stressing the lack of effective action from below in modern Russia, the author deems the Union of Committees of Soldiers' Mothers of Russia atypical, based on its assistance for over twenty years to individual families which has led to its accepted position as a key player in the public debate on the conditions of compulsory military service.

2 In contrast to previous analyses of the structure and organisation of its central and regional committees, Colin Lebedev places her emphasis on the ordinary people at the heart of the organisation: the individual petitioners and volunteers linked by the empathy of one soldier's mother for another. This bottom-up approach brings a fresh perspective to the movement as the author traces the complex processes and mechanisms of interaction between actors as she tracks personal concerns brought to the Moscow Committee by individual letter-writers in the provinces through to an outcome of concerted political lobbying for the reform of compulsory military service. 
3 Scholarship on social interaction in the new Russia has often concentrated on practices of self-reliance through (unofficial) personal connections, ${ }^{1}$ while studies of the Soldiers' Mothers movement have focused rather on its collective action in the public sphere. ${ }^{2}$ Through the prism of pragmatic sociology, Colin Lebedev successfully fuses the personal and the public approaches, attempting a holistic analysis of the complex interaction between "big' and "small" actors, the official and the vulnerable, through the potentially conflicting concepts of "civic" and "domestic" worth. Actively seeking continuity with the Soviet past as a basis for intervention and the implementation of change, the author traces the idea of motherhood embedded in the Russian tradition and the Soviet principle of the state's duty of care for the citizen as part of an implicit social contract still linking the state and the individual. It is in the reconciliation of care and rights as two sides of social justice that the movement mediates between the family of a soldier and the military authorities.

4 The analysis is based on a rich body of letters written in the 1990s by petitioners, mainly mothers, to the Moscow Committee on behalf of soldiers suffering mistreatment or perceived injustice. Although there is no indication as to how these letters were selected from the tens of thousands available, the examples discussed and those appended to the study are testaments to the complexity of family circumstances and the confusion surrounding the legal framework governing conscription. This evidence base is supplemented with more recent personal observations of volunteers in action and discussions with Committee members, with considerable weight given to senior movement member Valentina Mel'nikova, a longstanding collaborator of the author. It is perhaps this reliance on inside information that leads the author to privilege cases of successful intervention, with less scrutiny of the eventual outcome of complaints that have not been addressed due to lack of detail or insufficient justification.

5 Colin Lebedev analyses the work of the Moscow Committee from three perspectives: that of the individual petitioner seeking assistance; the volunteer implementing the administrative procedure necessary for the efficient running of the organisation; and the interaction of the movement with the state. Following an overview of the evolution of the organisation against the backdrop of the two Chechen wars in the 1990s (Chapter 1), the author teases out the subtleties of various letters from individual families to highlight the types of problems encountered during military service, for example mistreatment, health deterioration and even desertion. She further discusses a variety of extenuating circumstances that should legally have indicated deferment of conscription or exemption from service (Chapter 2). Attention in Chapter 3 turns to the collation of this information by volunteers in a comprehensive analysis of how individual problems are classified by the Committee in order to quantify them statistically, thereby rendering them more useful to the movement's political aims. The modes of engagement of a variety of volunteers, often recruited from the ranks of previous petitioners, come under the spotlight in Chapter 4, while Chapter 5 brings the state into the equation, as the organisation attempts to re-define the relationship between state and citizen. Finally, Chapter 6 examines the political dimension of the movement and its vision as a defender of human rights in Russia.

6 By using a multi-dimensional approach, Colin Lebedev succeeds in relating the personal and civic aspects of this organisation, demonstrating clearly how a request based on a private maternal concern can give rise to collective action in the public sphere, despite potential tension in the two main objectives of the movement. The author clearly 
demonstrates how, with direct recourse to this powerful organisation, anxious and vulnerable mothers have access to maternal links beyond the immediate family, resulting in an often increasing engagement with the movement and a higher estimation of their own civic worth. However, it is her detailed analysis of the personal problems faced that gives such an invaluable insight into the position of vulnerable soldiers and their families seeking natural justice, while the sometimes inventive solutions negotiated with the military authorities by the volunteers in an exercise of collaboration and compromise are testament to the ingenuity and determination of the members.

7 This nuanced examination of a bottom-up movement of civilians attempting to reform the military institutions in Russia succeeds in its analysis of the many facets of the Union of Committees of Soldiers' Mothers of Russia as it existed in the 1990s and early 2000s. The author only hints, however, at its more recent evolution in the Putin era, suggesting that any success won under $\mathrm{El}^{\prime}$ tsin has become more fragile in the twenty-first century. With the public focus of the movement increasingly on collective action in the international human rights field, this work provides a timely reminder of its grassroots beginning as a self-help group of soldiers' mothers in post-Soviet Russia.

\section{NOTES}

1. For example Alena Ledeneva, Russia's Economy of Favours: Blat, Networking and Informal Exchange (Cambridge : Cambridge University Press, 1998).

2. For example Elena Zdravomyslova, “Soldiers' Mothers Fighting the Military Patriarchy: Re-invention of Responsible Activist Motherhood for Human Rights' Struggle" in Ilse Lenz, Charlotte Ullrich and Barbara Fersch, eds., Gender Orders Unbound ? Globalisation, Restructuring and Reciprocity (Opladen/Farmington Hills : Barbara Budrich, 2007), 207-226.

\section{AUTEURS}

VICKY DAVIS

UCL-SSEES 